\title{
Strategi dan Model Pembinaan Rohani untuk Pendewasaan Iman Jemaat
}

\author{
Purim Marbun \\ STT Bethel Indonesia \\ marbunpurim@gmail.com
}

\begin{abstract}
This research is base on the problem of the pastor's inability the church to implement an effective community development program. Moreover, if this judged based on implementation of the chuch's vision and mision, many churches are not accurate incarrying out spiritual formation properly. Another problem is the lack of time the congregation participates in a coaching program implemented in the church will affect the congregation's lack of knowledge and understanding of God's word, this will affect the spiritual quality of the congregation. The research method used in this paper is a descriptive qualitative study of literature by examining various literatures relating to subject matter discussed. Through in-depth study and analysis, it is hoped that the pastors will provide concrete steps in planning and conducting effective coaching of church members. The result of this reseach to provide strategic steps and models of spiritual formation that are accurate and measurable and are able to increase the understanding of God's word and make the spiritually mature as measured by changes in behaviour.
\end{abstract}

Keywords: spiritual formation; spiritual growth; spiritual maturity

\begin{abstract}
Abstrak
Penelitian ini dilatarbelakangi masalah ketidakmampuan pendeta atau gembala dalam menyelenggarakan program pembinaan warga jemaat secara efektif. Apalagi jika hal ini dinilai berdasarkan implementasi visi dan misi gereja, banyak gereja tidak akurat melaksanakan pembinaan iman dengan baik. Masalah lain minimnya waktu jemaat mengikuti program pembinaan yang dilaksanakan di gereja akan berpengaruh pada rendahnya pengetahuan dan pemahaman jemaat akan firman Tuhan, hal ini akan mempengaruhi kualitas kerohanian jemaat. Metode penelitian yang digunakan dalam tulisan ini studi kualitatif deskriptif kepustakaan dengan menelaah berbagai literatur yang berkaitan dengan pokok masalah yang dibahas. Melalui kajian dan analisis yang mendalam diharapkan memberikan langkah-langkah konkrit bagi pendeta dalam merencanakan dan melakukan pembinaan warga gereja dengan efektif. Hasil penelitian ini memberikan langkah-langkah stategis dan model pembinaan rohani yang akurat dan terukur serta mampu meningkatkan pemahaman firman Tuhan serta menjadikan jemaat dewasa rohani yang diukur dari perubahan perilaku.
\end{abstract}

Kata Kunci: kedewasaan rohani; pembinaan rohani; pertumbuhan rohani 


\section{Pendahuluan}

Pembinaan warga gereja yang dapat disebut pembinaan iman adalah tugas dan tanggung jawab gereja kepada umat Tuhan. Tugas ini dilakukan gereja dalam rangka mengejawantahkan Amanat Agung yang berisi penginjilan, baptisan, dan pengajaran (Matius 28 :19-20). Secara khusus tugas mengajar jemaat dilakukan melalui program pembinaan rohani. Istilah yang lazim digunakan ialah pembinaan warga gereja. Pelayanan pembinaan rohani membutuhkan kesiapan gereja baik secara konten maupun cara pelaksanaanya, ini adalah tanggung jawab para hamba Tuhan (pendeta atau gembala jemaat) di gereja tersebut.

Perintah "mengajar" seperti dijelaskan dalam Matius 28:19-20, pada awalnya merupakan perintah dan amanat Yesus Kristus kepada murid-murid-Nya. Namun dalam kekinian tugas ini merupakan tanggung jawab gereja. Gereja tidak hanya membangun persekutuan, namun juga mendidik dan mengajar. Beberapa panggilan gereja yaitu proklamasi (kerygma), persekutuan (koinonia), pelayanan (diakonia), nubuat (propheteia), dan ibadah (leitourgia), dan mengajar (didache) menjadi penghubung di antara semuanya.

Pelaksanaan pembinaan rohani kepada jemaat dapat berlangsung dengan baik jika memperhatikan beberapa hal yang menjadi patokan dasar antara lain: pertama, tugas yang diamanatkan sesuai dengan Alkitab. Mengajar (to teach), sering juga diartikan melatih, membina dan membawa perubahan yang dialami oleh jemaat. Kedua, pembinaan rohani jemaat penting berkaitan dengan pembentukan karakter. Nuhamara menjelaskan bahwa salah satu upaya membangun karakter ialah dengan meningkatkan nilai-nilai (values) kehidupan melalui pendidikan baik secara formal maupun informal. ${ }^{1}$ Pendidikan secara formal dilakukan oleh lembaga-lembaga pendidikan resmi, sedangkan pendidikan nonformal dilakukan oleh gereja dan keluarga. Pembinaan rohani adalah salah satu program yang dapat dilakukan oleh gereja. Selain untuk pertumbuhan karakter salah satu fungsi dari pembinaan iman yakni membawa jemaat-jemaat mengalami kebangunan rohani. Carmeling dan Wijaya menjelaskan bahwa kebangunan rohani ditandai dorongan melakukan misi adalah bagian dari pembinaan iman. ${ }^{2}$ Jemaat yang mendapat pembinaan rohani akan mencapai kedewasaan yang dibuktikan dengan panggilan bermisi. Ketiga, pembinaan rohani bertalian dengan upaya mengatasi degradasai moral. Dalam konteks ini gereja memiliki tugas yang berat mengerjakan pembinaan dalam rangka meningkatkan standart moral jemaat yang sesuai dengan Alkitab. Sembiring menjelaskan bahwa hal degradasi moral sangat mudah ditemukan di gereja, karena fakta-fakta nyata ada terjadi seperti aborsi, pelanggaran seksual, perjinahan, dan lain-lain. ${ }^{3}$ Selain hal ini, masih dapat ditemukan persoalan-persoalan etika dalam kehidupan warga jemaat, yang mengharuskan gereja melakukan program-program pembinaan rohani.

Salah satu alasan mendasar pentingnya pembinaan rohani seperti dijelaskan Sumarto yakni kesulitan jemaat-jemaat memilih antara nilai-nilai adat atau firman Tuhan. Dalam penelitiaannya di Toraja menjelaskan bahwa penghayatan nilai-nilai adat yang lebih dominan dibanding firman Tuhan. ${ }^{4}$ Persoalan tentang relasi adat dan iman Kristen memang

${ }^{1}$ Daniel Nuhamara, "Pengutamaan Dimensi Karakter Dalam Pendidikan Agama Kristen," Jurnal Jaffray 16, no. 1 (2018): 93.

2 Yosua Feliciano Camerling and Hengki Wijaya, "Misi Dan Kebangkitan Rohani: Implikasi Misi Allah Bagi Gereja," Jurnal Ilmiah Religiosity Entity Humanity (JIREH) Vol 1 (1)2019: 57-71.

${ }^{3}$ Ngendam Sembiring, "Mengatasi Degradasi Moral Melalui Pembinaan Warga Gereja," ILLUMINATE: Jurnal Teologi dan Pendidikan Kristiani Vok 1(1) 2018: 22-42.

4 Yonathan Sumarto and Peter Anggu, "Pembinaan Kerohanian Gereja Bethel Tabernakel Dalam Konteks Kebudayaan Toraja," Jurnal Jaffray 8, no. 1 (2010): 24-34, https://ojs.sttjaffray.ac.id/JJV71/article/view/39. 
menjadi pelik jika jemaat-jemaat tidak mendapatkan pembinaan rohani yang mendalam. Dalam banyak kasus jemaat banyak terjebak praktek-praktek yang tidak menyenangkan Tuhan dengan mengutamakan adat istiadat. Misalnya, upacara kematian yang sarat dengan hal-hal magis, juga upacara pernikahan yang cenderung memetingkan nilai-nilai adat yang bertentangan dengan firman Tuhan. Alkitab telah menjelaskan bahwa Allah menolak adat istiadat seperti dijelaskan dalan Injil Matius 15:7-9. Alkitab menegaskan mereka yang menjalankan adat istiadat dan mengutamakannya sama dengan orang munafik. Berbeda dengan ulasan Sumarto, Tafonao menyoroti perihal fungsi dan tugas gembala atau pendeta dalam tugas mengajar jemaat-jemaat. Menurutnya tugas ini sangat signifikan dalam rangka pembinaan rohani jemaat. ${ }^{5}$ Selanjutnya, Yachina menjelaskan bahwa fungsi pembinaan jemaat (spiritual formation) memiliki peran yang besar bagi pertumbuhan iman, moral dan kerohanian. ${ }^{6}$ Dalam konteks gereja pendeta atau gembala memiliki peran yang strategis dalam melaksanakan pembinaan warga jemaat untuk mendewasakan kerohanian mereka. Lebih lanjut pendeta tentunya terpanggil dan diberi tugas untuk melakukan tugas-tugas pastoral dengan tujuan jemaat mengalami kedewasaan rohani.

Masalah yang lain yang ditemukaan dalam implementasi pembinaan rohani ialah menyangkut pembaharuan karakter jemaat. Pembaharuan karakter meliputi perubahan sikap, pekataan, dan perilaku yang secara terus-menerus diupayakan oleh gereja melalui para pelayan Tuhan. Pembinaan rohani merupakan sarana penting untuk membawa jemaat mengalami perubahan seperti dijelaskan di atas. Diana dalam penelitiannya menjelaskan, masyarakat Kewari setelah menjadi Kristen membutuhkan pembinaan secara intens, meskipun hal itu sulit dilakukan. Dalam risalah penelitiannya disebutkan bahwa mengubah pola hidup lama kepada hidup baru adalah hal yang sulit, cenderung jemaat-jemaat kembali kepada kebiasaan-kebiasaan lama. ${ }^{7}$

Dalam pengamatan peneliti di beberapa gereja di Jakarta, khususnya wilayah Jakarta Barat, kendala-kendala yang dihadapi gereja-gereja dalam melakukan tugas pembinaan rohani, di antaranya: pertama, minimnya waktu gereja yang digunakan secara khusus dalam membina jemaat-jemaat. Sudah menjadi kenyataan bahwa gereja lebih fokus kepada peribadahan (ibadah raya) yang dilakukan setiap minggunya. Kedua, ada kecenderungan kesulitan bagi gereja (pendeta atau gembala) melakukan program-program pembinaan, secara khusus yang bertajuk pengajaran. Hal ini memengaruhi pengertian akan firman Tuhan dan sekaligus juga memengaruhi tingkat kedewasaan iman. Ketiga, pembinaan rohani yang dilakukan konvensional hanya melalui layanan khotbah mimbar. Hal ini lebih bersifat umum dan tidak mampu menyelami secara spesifik pergumulan jemaat-jemaat secara pribadi.

Berdasarkan latar belakang di atas, pertanyaan penelitian yang hendak dijawab dalam tulisan ini yakni bagaimana langkah-langkah strategis pembinaan rohani yang mampu mendewasakan jemaat secara rohani? Bagaimana model pembinaan warga jemaat yang efektif dilakukan oleh pendeta atau gembala sehingga mampu mendewasakan jemaat?

5 Talizaro Tafonao, "Peran Gembala Sidang Dalam Mengajar Dan Memotivasi Untuk Melayani Tehadap Pertumbuhan Rohani Pemuda," Evangelikal: Jurnal Teologi Injili dan Pembinaan Warga Jemaat 2, no. 1 (2018): 85-92.

${ }^{6}$ Nadezhda Yachina, "The Problem of Spiritual and Moral Formation of Personality," Procedia - Social and Behavioral Sciences 197, no. February (2015): 1575-1579.

7 Ruat Diana, "Permasalahan Pembinaan Warga Gereja Di Kewari," Evangelikal: Jurnal Teologi Injili dan Pembinaan Warga Jemaat (2018). 


\section{Metode Penelitian}

Penelitian ini berbasis studi kualitatif kepustaakan (library research). Peneliti menggali, membaca, dan menggunakan sumber-sumber literatur yang berhubungan dengan masalah yang diteliti dalam tulisan ini, serta menjelaskan topik strategi pembinaan rohani yang efektif. ${ }^{3}$ Selanjutnya penulis melakukan analisis deskriptif ${ }^{9}$ dipakai menjelaskan langkah-langkah strategis pembinaan rohani dan menentukan model pembinaan warga gereja yang efektif dalam mendewasakan kerohanian jemaat.

\section{Hasil dan Pembahasan Hakikat Pembinaan Rohani}

Istilah pembinaan rohani memiliki keragaman perspektif yang dipahami oleh gerejagereja, baik oleh pendeta maupun jemaat. Istilah yang dipakai di antaranya pembinaan iman, pembinaan warga gereja, pembinaan jemaat, dan lain sebagainya. Istilah ini hendak menggambarkan kegiatan yang dilakukan oleh gereja dalam hal ini pendeta atau gembala menolong jemaat agar bertumbuh dalam pengenalan Yesus Kristus sebagai Tuhan dan Juruselamat.

Secara konseptual istilah pembinaan rohani jika dikaitkan dengan gereja lokal, Ruth Selan menjelaskan bahwa pembinaan adalah usaha melengkapi warga gereja agar berfungsi sebagai anggota tubuh Kristus melalui program-program gereja dimana jemaat dipersiapkan memperoleh pengetahuan dan ketrampilan dalam pelayanan. ${ }^{10}$ Dalam pengertian ini terkandung usaha yang dilakukan oleh pendeta atau gembala jemaat menyiapkan layanan yang terstruktur membawa jemaat menjadi pribadi yang berubah dari jemaat biasa menjadi pelayan Tuhan. Senada dengan pengertian ini, tujuan utama pembinaan warga jemaat ialah membawa semua jemaat bersekutu dalam Kristus dan bertumbuh menjadi dewasa dalam pengenalan akan Dia. Salah satu tanda bahwa jemaat bertumbuh dan dewasa mereka mengambil tanggung jawab dalam pelayanan. ${ }^{11}$

Jika membaca dan membahas 2 Tim 3:15-17, prinsipnya pokok tentang pembinaan rohani bertujuan menjadikan jemaat mengenal firman Tuhan, tentu pada bagian ini gereja bertanggung jawab memperkenalkan dan mengajarkan Alkitab secara terencana. Gereja dapat memberikan layanan pembacaan Alkitab secara berkala atau dengan mengikuti bacaan Alkitab setahun. Selain ini tentu esensi dari kitab 2 Tim. 3:15-17 memberikan pengajaran, sehingga mereka mampu memahami kesalahan-kesalahan, meninggalkan kesalahan, dan berproses hidup dalam pertobatan yang sungguh-sungguh.

Pembinaan rohani yang dilakukan dalam gereja selalu berbasis Alkitab atau firman Tuhan. Beberapa alasan mendasar mengapa gereja mendasarkan pembinaan warga gereja dengan Alkitab, yakni: pertama, pengertian dan pemahaman tentang hal-hal rohani tidak ditemukan dalam buku mana pun selain dari Alkitab. Karena Alkitab secara fundamental memberikan tatanan dan nilai-nilai rohani, maka tidaklah tepat mengabaikan hal ini, justru sebaliknya apapun layanan pembinaan rohani kepada jemaat berpedoman pada Alkitab. Kedua, firman Tuhan adalah berita utama yang sangat relevan dan signifikan untuk pembinaan kerohanian. Salah satu implikasi pembinaan bermuara kepada karakter yang dimiliki jemaat-jemaat. Jika berita utama firman Tuhan disampaikan melalui pembinaan rohani, niscaya karakter jemaat akan terbangun dengan baik. Ketiga, pembinaan rohani mengisyaratkan hal-hal yang menyentuh spiritualitas. Dalam konteks kehidupan jemaat halhal spiritual utamanya dipaparkan sesuai pemahaman firman Tuhan. Tiga hal di atas secara

8 Sugiyono, Metode Penelitian Kualitatif (Bandung: Alfabeta, 2009).

${ }^{9}$ Lexy L. Moleong, Metode Penelitian Kualitatif (Bandung, 2004).

${ }^{10}$ Ruth F Selan, Pedoman Pembinaan Jemaat (Bandung: Kalam Hidup, 2006),22.

11 Purim Marbun, Pembinaan Jemaat, (Jogjakarta: Andi Offset, 2017), 10. 
prinsip tidak mungkin digeser, apapun hal yang menyangkut pembinaan rohani selalu bermuara kepada firman Tuhan.

Berdasarkan paparan di atas, hakikat pembinaan rohani dapat diartikan sebagai usaha gereja melakukan pelayanan pembinaan dan pengajaran kepada jemaat berdasarkan firman Tuhan. Usaha ini bertujuan membawa jemaat bersekutu dengan Tuhan dan menjadi dewasa dalam rohani yang dibuktikan dengan keterlibatannya dalam panggilan melayani.

\section{Program-Program Pembinaan Rohani}

Gereja sebagai lembaga rohani didalamnya terdapat persekutuan dan pengajaran tidak bisa dipisahkan dari tugas pembinaa rohani. Gereja adalah lembaga ilahi yang didirikan oleh Tuhan Yesus Kristus dengan tugas mengajar dan mendewasakan umat (Mat. 16:18; 28:19-20). Tugas mengajar dilakukan dengan membuat program-program pembinaan secara terencana dan terprogram. Program pembinaan dapat dilakukan secara personal maupun bersama-sama, di dalam gereja maupun di luar gereja.

Program pembinaan warga gereja harus meliputi esensi bersaksi, mendidik dan melayani. Fungsi gereja sebagai wadah beribadah, bersaksi, mendidik, dan melayani hanya dapat dilaksanakan ketika gereja membuat program yang sesuai dengan tajuk di atas. Program yang terkait dengan peribadahan dapat diselenggarakan dalam persekutuan (koinonia) baik secara kategorial maupun bersama-sama. Program bersaksi dilakukan dengan mendorong jemaat mengkomunikasikan injil dan pengalaman-pengalaman rohani kepada orang lain, sedangkan program mendidik dilaksanakan dengan pengajaran, misalnya melalui katekisasi, pendalaman Alkitab dan lain-lain.

Dalam Injil Matius 28:20, salah satu hal penting diperhatikan dan diimplikasikan oleh para gembala sidang adalah "ajarlah mereka melakukan." Kalimat ini merupakan tugas sekaligus tanggung jawab pemimpin rohani. Teks ini mendorong pemimpin gereja (pendeta, gembala jemaat) harus menyusun program pembinaan melalui pengajaran kepada jemaatjemaat. Pengajaran yang dilakukan gereja bertujuan mengubah tingkah laku dan sifat umat Allah (jemaat). Untuk tujuan ini diperlukan bukan hanya transfer pengetahuan tetapi mengembangkan kemampuan dan sikap serta motivasi. Gereja perlu menekankan pertumbuhan karakter dan dorongan kepada jemaat untuk menjadi saksi, teladan dan berdampak di tengah kehidupan masyarakat.

Program pembinaan rohani di gereja dapat dilakukan dengan pengajaran iman yang dalam beberapa bentuk yakni: pertama, ajaran gereja (instruction). Ini merupakan pemberian informasi tentang fakta-fakta, seperti Alkitab, sejarah gereja, atau doktrin (ajaran-ajaran) Kristen. Para pendeta dan gembala jemaat tidak cukup hanya mengajar melainkan mengkorelasikan dengan iman dan kehidupan sehari-hari. Ajaran gereja harus diikuti dengan pemahaman yang mendalam dan dikomunikasikan dengan bahasa yang mudah dimengerti oleh jemaat.

Kedua, pendidikan gereja. Pengajaran di sini melibatkan keseluruhan pribadi jemaat dalam proses belajar dan meliputi keterampilan, kebiasaan, sikap, serta penilaian.Tugas gembala dan pendeta dalam konteks ini mengembangkan berbagai aspek kemampuan rohani yang membawa mereka bukan saja hanya memiliki pengetahuan rohani melainkan juga cakap dalam menerapkannya. Pendidikan ini lebih menekankan pola-pola pengajaran yang mendorong jemaat memiliki kecakapan tertentu dalam berbagai hal yang sifatnya teknis, misalnya keterampilan melayani.

Ketiga, pembinaan gereja. Istilah pembinaan jika dikaitkan dengan pemahaman "nurture" artinya membina dan mengasuh. Program pembinana yang dilakukan oleh gereja mengandung esensi pendidikan, juga meliputi perkembangan, latihan, dan asuhan. Jika program pembinaan ini dilakukan dalam jemaat, maka salah satu hal yang dipelihara ialah iklim pembinaan iman yang tujuannya adalah penyerahan diri kepada Tuhan. Membina dan 
mengasuh jemaat dalam konteks pembinaan rohani, pada prinsipnya akan mendewasakan kerohanian.

Ruang lingkup pembinaan rohani dalam gereja meliputi semua umur. Ruth Selan menjelasakan bahwa sasaran pembinaan rohani ditujukan kepada jemaat-jemaat dari segala lapisan umur, baik dewasa, pemuda, remaja dan anak-anak, pria dan wanita dalam gereja. Program ini dilakukan sejak mereka percaya kepada Kristus, dan akan berlangsung selama hidup. ${ }^{12}$ Senada dengan penjelasan ini, kategori pembinaan rohani dapat dibedakan secara klasifikasi usia mulai dari anak-anak sampai kepada lansia. Namun pembinaan rohani juga dapat dikategorikan menurut level kerohanian jemaat misalnya petobat baru dan mereka yang dewasa rohani. ${ }^{13}$ Keseluruhan program pembinaan warga gereja ini dilakukan secara internal dan didalam gereja lokal, dan merupakan tugas pendeta atau gembala jemaat.

Pelaksanaan pogram pembinaan rohani adalah upaya gereja membina rohani jemaatjemaat untuk mengalami pembaharuan atau transformasi kehidupan yang ditandai dengan adanya perubahan-perubahan dalam kehidupan sehari-hari. ${ }^{14}$ Oleh karena itu, program pembinaan rohani yang tidak bisa dihilangkan dari gereja adalah mengajar. Mengajar memiliki kedudukan yang esensial dalam gereja, khusus dalam kaitan pembinaan rohani yang memiliki sasaran mengubah kehidupan, nilai-nilai kehidupan terbentuk dengan baik dan menjadikan jemaat hidup sesuai dengan firman Tuhan.

\section{Pendeta atau Gembala dan Tugas Pembinaan Jemaat}

Sebelum menjelaskan tugas dan fungsi utama pendeta dalam pembinaan jemaat, ada baiknya dipahami siapa yang disebut pendeta? Julukan ini dikenakan kepada orang atau pribadi yang terpanggil dan diutus Tuhan melayani jemaat-jemaat. Dalam pemahaman yang lebih komprehensif pendeta adalah orang yang dipanggil oleh satu atau beberapa jemaat melayani dalam kurun waktu tertentu dalam konteks tugas pastoral. Pendeta juga bisa dikenakan kepada mereka yang melayani secara organisatoris oleh sinode atau pimpinan gereja tertentu sesuai dengan kebutuhan lapangan pelayananan.15 Dari pemahaman di atas dapat disebutkan bahwa pendeta ialah seseorang yang terpanggil dalam pelayanan gerejawi, ditahbiskan secara sinodal untuk tugas-tugas pembinaan dan pengajaran jemaat-jemaat sesuai dengan firman Tuhan.

Lebih lanjut jika dikaitkan dengan gembala jemaat, mereka adalah pendeta yang ditugaskan memimpin satu jemaat lokal. Gembala bertanggung jawab melakukan pelayanan pastoral baik secara umum maupun secara khusus. Dalam menjalankan tugasnya sebagai pemimpin jemaat, tugas kepemimpinan sangat terkait dengan pengangkatan yang dilakuakan sinode. Jadi pendeta dan gembala jemaat dalam satu posisi tertentu bisa digabungkan jika melihat kepada letak dan fungsinya kepada jemaat lokal, namun bisa juga dipisahkan. Pendeta hanya untuk urusan kependetaan atau jabatan gerejawi, namun gembala adalah tugas fungsional.

Tugas pembinaan jemaat secara khusus dalam gereja lokal utamanya dilakukan oleh pendeta atau gembala jemaat, meski tidak semua pendeta dan gembala memiliki karunia dan kemampuan melakukan hal tersebut. Dalam pengelaman peneliti sebagai pendeta jemaat setiap tahun harus merumuskan bahan-bahan pengajaran (komsel), yang disiapkan

\footnotetext{
12 Ruth F. Selan, Pedoman Pembinaan Jemaat.

13 Purim Marbun, Pembinaan Jemaat, 12.

14 Francis O. Ayres, Pembinaan Warga Gereja Pelayanan Kaum Awam, ed. Putri Kapandeyan, Pertama. (Malang: Gandum Mas, 2016), 15.

${ }^{15}$ Robert P. Borrong, Melayanui Makin Sungguh: Signifikansi Kode Etik Pendeta Bagi Pelayanan Gereja-Gereja Di Indonesia (Jakarta: BPK Gunung Mulia, 2016), 16.
} 
sesuai tema pelayanan tahunan. Bahan itu disiakan dalam bentuk tulisan dan kerangka materi sharing, yang diajarkan setiap minggunya.

Klasifikasi tugas pendeta dan jabatannya dalam pelayanan gerejawi dapat dibedakan dalam tiga cara pandang yang berbeda, antara lain: pertama, sebagai karunia Tuhan. Dalam kitab Efesus 4:11-16, menyebutkan: "Dan Ialah yang memberikan baik rasulrasul maupun nabi-nabi, baik pemberita-pemberita Injil maupun gembala-gembala dan pengajarpengajar, untuk memperlengkapi orang-orang kudus bagi pekerjaan pelayanan, bagi pembangunan tubuh Kristus, sampai kita semua telah mencapai kesatuan iman dan pengetahuan yang benar tentang Anak Allah, kedewasaan penuh, dan tingkat pertumbuhan yang sesuai dengan kepenuhan Kristus, sehingga kita bukan lagi anak-anak, yang diombang-ambingkan oleh rupa-rupa angin pengajaran, oleh permainan palsu manusia dalam kelicikan mereka yang menyesatkan, tetapi dengan teguh berpegang kepada kebenaran di dalam kasih kita bertumbuh di dalam segala hal ke arah Dia, Kristus, yang adalah Kepala. Dari pada-Nyalah seluruh tubuh,--yang rapih tersusun dan diikat menjadi satu oleh pelayanan semua bagiannya, sesuai dengan kadar pekerjaan tiap-tiap anggota-menerima pertumbuhannya dan membangun dirinya dalam kasih".

Berdasarkan teks ini, jabatan pendeta dipahami sebagai karunia yang harus digunakan melengkapi jemaat-jemaat agar jemaat mengalami pertumbuhan kearah kedewasaan. Dalam hal ini karunia pendeta dapat dibedakan sebagai rasul, nabi, guru, penginjil, dan gembala. Jika melihat kelima jabatan atau karunia ini, maka semuanya bertujuan membawa jemaat mengalami pertumbuhan kearah kesempurnaan, dalam hal ini niscaya ada tugas pembinaan yang dilakukan dengan intens.

Kedua, sebagai pemimpin jemaat. Pada tataran ini yang perlu mendapat perhatian ialah fungsi pendeta mengarahkan, membina, dan menuntun jemaat untuk berjalan sesuai dengan rencana Tuhan. Pendeta sebagai pemimpin harus hadir sebagai figur yang lebih dewasa, mumpuni dan terampil menggembalkan jemaat. Tugas utamanya ialah memberi layanan pastoral sehingga jemaat-jemaat dapat hidup sesuai dengan firman Tuhan, dan mereka bertumbuh ke arah kedewasaan rohani. Fungsi kepemimpinan dalam hal ini tidak saja hanya menyentuh aspek-aspek manajaerial melainkan tugas penggembalaan yang akurat dan menyentuh kehidupan rohani jemaat.

Ketiga, sebagai pengajar, pada bagian ini seorang pendeta pasti terlibat dalam program pendidikan jemaat. Pendidikan jemaat yang dimaksud tentu bukan secara akademis melainkan lebih kepada tugas mengarahkan, mendorong, melatih dan mengajar jemaat secara rohani. Sebagai pengajar jemaat, tugas pendeta menjelaskan firman Tuhan sehingga jemaat memiliki pengertian dan pemahaman yang jelas. Lebih lanjut dari pengajaran tersebut tentu jemaat akan dituntun kepada dasar-dasar yang jelas dan kokoh tentang iman kristen. Tugas mengajar merupakan tanggung jawab yang tidak mungkin dipisahkan dari fungsi pendeta. Dialah pribadi yang dipilih dan ditetapkan Tuhan untuk mengajar jemaat, sehingga jemaat bertumbuh dalam pengenalan akan Tuhan.

Tugas pembinaan jemaat yang dilakukan oleh pendeta atau gembala jemaat, sangat terkait dengan teks Alkitab dalam 1 Tim 4:6-11, para gembala memiliki tugas menjadi pengajar dalam jemaat-jemaat. Tafonao melaporkan dalam penelitiannya bahwa hal yang sangat signifikan membangun kerohanian dalam jemaat ialah jika gembala atau pendeta melakukan tugas mengajar dengan baik. Disebutkan bahwa pengaruh fungsi gembala sebagai pengajara memiliki dampak yang signifikan bagi pertumbuhan rohani jemaatjemaat.16 Secara konsep biblikal memang gembala atau pendeta, bertanggung jawab mengajar jemaat-jemaat, bahkan juga membawa mereka bertumbuh dalam kerohanian.

16 Tafonao, "Peran Gembala Sidang Dalam Mengajar Dan Memotivasi Untuk Melayani Tehadap Pertumbuhan Rohani Pemuda." 
Lebih lanjut, Berhitu menyebutkan bahwa peran dan fungsi pendeta atau gembala dalam gereja lokal bersifat holitik. Yang dimaksud dengan holistik bahwa pendeta bukan hanya dalam konteks mengajar jemaat, namun juga dalam menolong jemaat dalam berbagai pelayanan seperti diakonia, menjaga keutuhan jemaat bahkan juga merencanakan program gereja yang dinamis. ${ }^{17}$ Berdasarkan kajian ini, maka tugas dan peran pendeta dalam jemaat sangat holistik, bukan hanya pembinaan kerohanian, namun juga mencakup unsur-unsur manajerial dalam pelayananan.

Tugas dan tanggung jawab pendeta dalam pembinaan rohani pada prinsipnya bertitik tumpu kepada job description dalam gereja lokal. Tugas ini tentu harus dikategorikan dalam konteks organisasi gereja lokal, dalam hal ini aspek-aspek manajemen menjadi dasar pijak tugas yang dilakukan. Pendeta atau gembala sebagai pimpinan tertinggi dalam jemaat, bertanggung jawab bagi keseluruhan pelayanan dan juga semua orang yang terlibat di dalamnya. Sebaliknya dalam konteks tugas pembinaan rohani, maka pendeta atau gembala tidak mungkin melakukannya jika tidak memiliki karunia mengajar.

Dalam gereja-gereja modern memang tugas mengajar dan membina jemaat, bukan lagi tugas personal gembala. Namun sudah berkembang menjadi bagian divisi atau bidang pendidikan dan pengajaran. Misalnya digereja-gereja tertentu ada komisi pengajaran dan teologi, bidang pendidikan dan latihan, atau komisi pembinaan warga gereja. Sebutan apapun yang dikenakan pada tugas ini di gereja lokal esensinya bidang tersebut bertugas melakukan pembinaan rohani kepada jemaat-jemaat.

Ruth Selan menegaskan bahwa tugas pembinaan rohani sesuai dengan landasan Alkitab dalam Efesus 4:11-16, minimal memiliki beberapa kriteria antara lain: tujuan pembinaan rohani untuk mendewasakan jemaat-jemaat, pembinan ini dilakukan oleh pendeta atau gembala yang memiliki karunia mengajar, hasil dari pembinaan rohani menjadikan jemaat memiliki relasi yang harmonis dengan Kristus dan berperan aktif dalam pelayanan.18 Dengan melihat kepada bagian ini, maka sesungguhnya pembinaan rohani tidak bisa dilepaskan dari karunia mengajar yang dimiliki oleh pendeta atau gembala jemaat. Senada dengan hal ini, karunia yang besar dan berpengaruh dalam tugas pembinaan warga gereja ialah mengajar ${ }^{19}$.

Dalam melaksanakan tugas pembinaan rohani kepada jemaat-jemaat, berbagai program pendidikan yang dapat dilakukan oleh pendeta di antaranya: katekisasi, pendalaman Alkitab, kelas diskusi firman Tuhan, dan lain-lain. Katekikasi dapat dilakukan dalam konteks tertentu seperti membagi kelompok yang akan menerima baptisan, pernikahan, dan lain-lain. Dalam arti luas, katekisasi harus mencakup pra dan pasca setiap kegiatan yang dilakukan di gereja. Pendalaman Alkitab dalam dilakukan seperti pengajaran praktis yang membawa jemaat bertumbuh dalam pengenalan firman Tuhan, sekalipun dalam konteks yang lebih dalam pendalaman Alkitab dapat menyentuh hal-hal yang bersifat doktrinal atua dogma. Diskusi-diskusi Alkitab dapat dilakukan sesuai dengan kebutuhan, misalnya ada isu-isu yang penting mendapat tanggapan secara teologis, pendeta, atau gembala jemaat bertanggung jawab melakukan hal ini.

Pendeta atau gembala jemaat tidak mungkin dipisahkan dari tugas pembinaa rohani. Semua tugas pendeta atau gembala pasti terkait dengan tanggung jawab mendewasakan jemaat, hal yang sangat sederhana dapat dilakukan dalam tugas-tugas pelayanan mimbar atau khotbah. Ini sering disebut dengan layanan pastoral umum, melalui khotbah pendeta

${ }_{17}$ Reinhard Jeffray Berhitu, "Peran Gembala Jemaat Terhadap Pengembangan Pelayanan Holistik Di Gereja Kemah Injil Indonesia Jemaat Yegar Sahaduta Jayapura," Jurnal Jaffray 12, no. 2 (2014): 273.273

18 Ruth F.Selan, Pedoman Pembinaan Jemaat.

${ }_{19}$ Purim Marbun, Pembinaan Jemaat, 18 
harus mendidik dan mengarahkan jemaat-jemaat kepada pencapaian tingkat kedewasaan iman. Khotbah bukan hanya sekedar layanan biasa setiap minggu di mimbar gereja melainkan berhubungan dengan upaya mendewasakan kerohanian. Itulah sebabnya pendeta harus merumuskan tujuan dan tema-tema khotbah yang mengajar jemaat menjadi dewasa. Umumnya khotbah-khotbah yang bersifat pengajaran akan otentik mendorong jemaat bertumbuh dan dewasa.

Tugas pembinaan rohani bagi jemaat bukanlah pilihan bagi pendeta atau gembala, melainkan tugas wajib. Teks firman Tuhan dalam Efesus 4:11-16 dan Matius 28:19-20, menetapkan mengajar dan mendidik jemaat. Dalam rangka mengerjakan tugas dan tanggung jawab ini para pendeta dijemaat harus merancang metode-metode yang efektif dalam mengajar dan mendidik warga gereja. Gembala jemaat atau pendeta memerlukan kecakapan dan ketrampilan khusus sebagai guru (teacher) di jemaat. Ia bukan saja hanya berkhotbah (preaching) melainkan mengajar (teaching) firman Tuhan yang menjadi kebutuhan jemaat.

\section{Strategi Pelaksanaan Pembinaan Rohani yang efektif}

Pokok permasalahan tentang bagaimana melakukan pembinaan rohani yang efektif haus memperhatikan beberapa hal yakni program yang tepat, pola pembinaan, program yang kreatif dan karakter pemimpin rohani. Keempat hal ini akan dijelaskan secara detail seperti di bawah ini.

\section{Memilih Program yang Tepat}

Salah satu aspek yang perlu diperhatikan dalam melakukan pembinaan rohani ialah program yang dilakukan harus tepat guna. Program yang tepat dimaksudkan harus mencerminkan berbagai unsur di antaranya sesuai visi dan misi gereja, memenuhi kebutuhan jemaat setempat dan juga dilakukan sesuai dengan tingkatan kerohanian jemaatjemaat. Terkait dengan pembinaan rohani yang harus sesuai dengan visi. Visi merupakan hal yang sentral dalam merancang program pembinaan warga gereja. Dengan memahami visi gereja, gembala atau pendeta, bidang teologi dan pendidikan di jemaat lokal mampu merumuskan program yang tepat. ${ }^{20}$ Secara tata laksana visi gereja akan diaktualisasikan menjadi program-program pembinaan, baik pembinaan jangka pendek, menengah dan jangka panjang. Visi gereja melandasi semua agenda pembinaan rohani dalam jemaat lokal, mulai dari pembinaan kategorial maupun secara umum. Juga termasuk pembinaan yang dilakukan secara individu maupun kelompok. Visi mendasari program pelayanan pembinaan yang dilakukan, itulah sebabnya ketika gembala atau pendeta merumuskan program harus berada dalam koridor visi.

Selain visi hal yang kedua yang perlu diperhatikan jenis program dan kesesuaian dengan usia kategorial. Pokok ini dimaksudkan agar program mampu dicerna oleh jemaatjemaat, maka hal yang mendasar dilakukan oleh pemimpin gereja mengerti sifat dan kebutuhan jemaat secara klasifikasi usia. Perhatian terhadap hal ini menjadi sangat perlu karena setiap usia kategorial memiliki kebutuhan (needs) yang berbeda-beda. Misalnya kebutuhan rohani anak-anak dengan pemuda pasti berbeda, demikian juga pemuda dengan orang tua. Sisi psikologis menjadi landasan yang perlu diperhatikan dalam merumuskan program pembinaan rohani.

Tuhumury melaporkan dalam penelitiaannya akan minimnya program pembinaan rohani yang dilakukan bagi usia pemuda di GKII Berau sulit memberi memberi dampak yang positif dan signifikan bagi pertumbuhan kerohanian. Dijelaskan bahwa program

${ }^{20}$ Purim Marbun, Pembinaan Jemaat, 20. 
pembinaan tidak mampu mendorong animo pemuda mengikuti pembinaan rohani. ${ }^{21}$ Supartini menjelaskan bahwa pembinaan merupakan hal yang prinsip dalam menumbuhkan kerohanian anak-anak.22 Dari paparan ini disimpulkan bahwa urgensi program pembinaan rohani yang sesuai kebutuhan dan usia kategorial akan mendorong keterlibatan jemaat dalam pembinan selanjutnya keterlibatan dalam pembinaan akan memberi ruang gerak yang memadai mengubah dan membawa pertumbuhan rohani bagi jemaat.

Pendeta atau gembala jemaat sangat bertanggung jawab merumuskan program yang sesuai kebutuhan jemaat. Karna itu salah satu hal yang dapat dilakukan sebelum merumuskan program pembinaan, melakukan need assesment sehingga mengetahui secara jelas kebutuhan rohani. Selain itu need assesment juga berguna menolong bangun rancang progam pembinaan dalam jangka panjang. Tim yang bertugas menyusun program pembinaan warga gereja akan mampu secara detail menyusun progran berbasis kebutuhan rohani. Hal yang ketiga perlu diperhatikan dalam menyusun program yang tepat yakni kesesuaian dengan konteks gereja tersebut. ${ }^{23}$ Yang dimaksud dengan konteks gereja disini memperhatikan budaya gereja setempat, ini bukan menyoal budaya masyarakat, namun tentang nilai-nilai yang menjadi panutan gereja lokal tersebut. Misalnya pembinaan dilakukan oleh mereka yang lebih senior, mempertimbangkan lama berjemaat atau keterlibatan dalam pelayanan. Hal-hal seperti ini secara tidak langsung mempengaruhi pola pikir jemaat, juga akan berimbas kepada keikutsertaan dalam program pembinaan rohani.

\section{Menerapkan Pola Pembinaan yang Akurat}

Penerapan pola pembinaan yang akurat sangat terkait dengan manajemen pelayanan yang diterapkan dalam gereja lokal. Program yang tepat seperti pada poin di atas tidak berdiri sendiri, harus dilanjutkan dengan pola pembinaan yang tepat. Dalam hal mengimplmentasikan pengorganisasian setiap kegiatan haruslah ditata dengan baik, bukan soal banyaknya program, namun cara melaksanakan dengan tepat. Tugas ini juga sangat erat kaitanya dengan pola profesionalisme pelayanan di gereja.

Aspek-aspek manajerial pelayanan yang diupayakan dalam konteks pembinaan yang akurat, memperhatikan perencanaan pembinaan, tujuan pembinaan, isi atau konten pembinaan, metode dan juga sistem evaluasi dalam konteks mengupayakan feedback. Lima hal aspek manajerial ini akan dijelaskan dengan runut dan detail. Pertama, perencanaan pembinaan meliputi jenis-jenis program yang akan dilaksanakan dalam gereja memberikan gambaran macam-macam pogram yang dilakukan. Misalnya, pendalaman Alkitab, konseling, kelompok sel, seminar keluarga, retreat, kelompok tumbuh bersama, dan lainlain. Jenis-jenis program ini harus direncanakan berdasarkan kesiapan gembala atau pendeta yang akan melaksanakannya, tentu dalam hal melaksanakannya secara implementatif dapat dilaksanakan tim yang telah dibentuk di gereja.

Perencanaan jenis-jenis pembinaan pada dasarnya harus dilakukan oleh pendeta berdasarkan tujuan yang akan diinginkan. Jika tujuannya hendak membawa pertumbuhan kerohanian, maka program pembinaan sebaiknya merujuk kepada pengajaran (teaching)

${ }^{21}$ Mika Mika and Petronella Tuhumury, "Implementasi Strategi Pembinaan Menuju

Pertumbuhan Rohani Pemuda Gkii Jemaat Sidu'ung Muara Berau," Jurnal Jaffray (2013).

22 Tri Supartini, "Implementasi Teologia Anak Untuk Mewujudkan Gereja Ramah Anak,"

Integritas: Jurnal Teologi Vol 1(1) 2019: 1-14,

http://journal.sttjaffrayjakarta.ac.id/index.php/JI/article/view/4/1.

${ }^{23}$ R.M. Drie S. Brotosudarmo, "Pembinaan Warga Gereja Selaran Dengan Tantangan Zaman," 2nd ed. (Jogjakarta: Andi OffSet, 2017), 197. 
yang berkelanjutan, 24 jika tujuannya hendak memberikan informasi yang memadai dan mendalam, maka jenis-jenis seminar yang informatif disajikan kepada gereja-gereja. Selanjutnya jika pembinaan diproyeksikan kepada pemberdayaan jemaat-jemaat, maka hal yang utama dilakukan dalam pembinaan ialah konsentrasi kepada pada pelatihan-pelatihan.

Dalam tugas merencanakan program pembinaan rohani, seorang gembala atau pendeta harus secara terbuka melibatkan pelayan-pelayan Tuhan yang memiliki karunia di bidang itu. Gidion menjelaskan bahwa salah satu upaya mengoptimalkan pelayanan gereja secara profesional harus memiliki tim yang kuat. Gereja harus memiliki sumber daya yang mumpuni serta tim pelayan yang kuat. ${ }^{25}$ Gembala atau pendeta tidak mungkin bekerja seorang diri, melainkan secara bersama-sama. Itulah sebabnya salah satu pergumulan dalam hal ini adalah memilih dan menetapkan tim kerja yang dapat melayani secara bersama-sama dalam tim.

Hal kedua yang prinsip dioperasionalkan dalam rangka menerapkan pola pembinaan yang akurat menyangkut tujuan pembinaan. Jenis program yang disusun tidak mungkin dipisahkan dari tujuan yang akan dicapai. Intisari dari program ada pada tujuan yang akan dicapai, karena itu dalam menentukkan jenis program pembinaan rohani. Program tanpa tujuan ibarat perjalanan yang tiada akhir, sebaliknya tujuan tanpa program ibarat impian yang diawang-awang. Pentingnya tujuan pembinaan dalam merumuskan program akan menolong pendeta atau gembala jemaat mengerti dan memahami target dan capaian dari program itu. Ini bertalian dengan proses pembuatan program dan isi program, tujuan memiliki urgensi antara lain: (1) menolong gereja merumuskan program yang tepat dan akurat. Dalam hal ini yang dimaksudkan ialah bahwa program yang direncanakan tidak berbasis kegiatan semata, melainkan program yang tepat sasaran. (2) menolong gereja fokus pada kegiatan yang efektif dan efisien, maksudnya gereja tidak terjebak dalam program oriented melainkan sasaran, tujuan, dan target. Dengan fokus pada beberapa program yang menunjang pertumbuhan kerohanian gereja akan lebih dinamis menjalankan program. (3) menolong gereja efisiensi pembiayaan program. Ini salah satu aspek yang harus diperhatikan oleh gereja dalam menyusun kegiatan, semua program pasti berbasis anggaran, untuk menghindari pembiayaan yang tidak efisien, maka selektif dalam membuat program akan menolong penghematan pembiayaaan. (4) menolong gereja melakukan program yang lebih berkualitas. Dengan memperhatikan tujuan pembinaan, program yang dilakukan sudah merupakan pilihan program yang diprediksi mencapai sasaran, dengan pola ini tentu akan bermuara pada lahirnya program yang berkualitas dan efektif.

Kemampuan merumuskan tujuan pembinaan pada dasarnya dipengaruhi pengalaman dan pendidikan pendeta atau gembala yang menyusunnya, tentu dua hal ini akan memberi pengaruh yang positif. Pengalaman dalam merumuskan tujuan akan menolong meng-update dan merevisi program-program yang lama, sehingga makin efisien. Latar belakang pendidikan berpengaruh karena secara akademis memiliki kompetensi dalam merencanakan program, mengkombinasikan tujuan-tujuan, bahkan mampu menyusun tahapan-tahapan pencapaian tujuan tersebut. Oleh karena penyusunan tujuan program sangat penting dalam pembinaan rohani, maka setiap pendeta perlu melibatkan tim yang lebih memahami dan mendalami kegiatan ini secara operasional.

Hal ketiga yang mendapat perhatian dalam menerapkan pola pembinaan yang akurat ialah memilih dan menetapkan konten pembinaan. Isi pembinaan merupakan aspek yang sangat prinsip diperhatikan, karena hal inilah yang akan mempengaruhi kegiatan itu

\footnotetext{
${ }^{24}$ Andar Gunawan Pasaribu and Rida Gultom, Pembinaan Warga Gereja, ed. Dane Taruli Simamora, Pertama. (Medan: Penerbit MITRA, 2015), 53.

${ }^{25}$ Gidion Gidion, “PROFESIONALITAS LAYANAN GEREJA," Jurnal Teologi dan Pelayanan Volume 7(2),2017:89-101.
} 
dilaksanakan. Program pembinaan rohani melahirkan tujuan, selanjutnya tujuan akan direalisasikan dengan isi atau konten pembinaan. Dalam konteks perencanaan kurikulum pembinaan, ada empat hal yang paling utama diperhatikan dan salah satunya ialah isi atau materi pembinaan. ${ }^{26}$ Materi pembinaan rohani yang dilakukan dalam gereja secara prinsip memiliki dua hal yang harus diperhatikan yakni isi atau materi berdasarkan Alkitab dan selalu Kristosentris. Materi pembinaan ini sering juga disebut dengan kurikulum, dalam bahasan Pendidikan Agama Kristen disebut rencana pembelajaran (pembinaan) yang secara terstrukstur membawa jemaat kepada pengajaran iman, ${ }^{27}$ dengan pengajaran iman jemaat akan dibawa bersekutu dengan Tuhan dan hidup dalam panggilan-Nya.

Materi berbasis Alkitab maksudnya bahwa rincian uraian materi yang disajikan setiap kali pembinaan bermuara pada firman Tuhan. Oleh karena pembinaan ini menyangkut hal-hal spiritual maka sumbernya harus Alkitab. Karena itu para pembina atau pengajar yang melakukan tugas pembinaan sudah seharusnya memiliki pengetahuan Alkitab yang memadai. Lebih lanjut bahwa agenda-agenda pembinaan yang dilakukan secara berkala, bertujuan mengupas tuntas tentang kerohanian seperti yang dijelaskan Alkitab.

Aspek kedua yang perlu diperhatukan bertalian dengan isi atau materi pembinaan harus berpusat pada Kristus. Isi dan materi tidak boleh melenceng kepada hal-hal yang bersifat humanistik, psikologis, dan sosiologis semata, melainkan mencerminkan Kristus. Jika harus membahas hal yang humanistik, psikologis, dan sosiologis harus didasarkan kepada landasan Alkitab yang tepat. Oleh karena pembinaan rohani bersifat teologis, maka tidak mungkin dipisahkan dari sentralitas yang Kristosentris.

Jika memperhatikan Efesus 4:11-16, sesuai dengan kutipan Ruth Selan, pembinaan warga gereja besifat teologis, tidak mungkin dipisahkan dari Alkitab sebagai landasannya dan Kristus sebagai pusat pemberitaannya. ${ }^{28}$ Materi harus menjelasan tentang Kristus, semua bahan yang disajikan kepada jemaat-jemaat menjelaskan tentang nilai-nilai yang berpusat pada Kristus. Karena itu pembinaan rohani dalam konteks gereja menolak masuknya nilai-nilai lain yang tidak berpusat pada Kristus.

Selain dari aspek Alkitab dan berpusat pada Kristus hal lain yang perlu mendapat perhatian dalam merumuskan isi pembinaan rohani yakni sesuai dengan kebutuhan rohani. Hal ini menjadi sangat relevan diperhatikan sebab jika memperhatikan jemaat-jemaat yang memiliki keragaman latar belakang, tingkat pendidikan dan juga kerohanian, maka tidaklah tepat menyajikan materi pembinaan yang serupa di tiap tingkatan. Juga termasuk tidaklah relevan mencampurbaurkan mereka yang telah dewasa rohani dengan petobat baru dalam pembinaan yang sama, karena itu setiap pendeta atau gembala jemaat dalam menyajikan materi pembinaan jemaat berdasarkan klasifikasi yang komprehensif.

Agar materi pembinaan dapat menyentuh kebutuhan rohani jemaat, beberapoa hal sangat mungkin dilakukn oleh gereja (dalam hal ini pendeta atua gembala jemaat) antara lain: (1) melakukan inventarisasi kebutuhan rohani berdasarkan deskripsi lamanya jemaat terhisap dalam gereja lokal; (2) membuat lembar evaluasi pelayanan tahunan terkait dengan pengukuran tingkat kerohanian; (3) membuat lembar kuestioner untuk mendapatkan umpan balik dari semua program yang telah dilakukan; (4) melakukan tes atau inventori kerohanian; (5) mengukur kesehatan gereja berdasarkan tes yang tersedia. Umpan balik dari kelima poin di atas akan memampukan gereja menyajikan materi yang akurat bagi jemaat.

${ }^{26}$ Purim Marbun, Pembinaan Jemaat, 22.

27 Imanuel P Tubulau, “Kajian Teoritis Tentang Konsep Ruang Lingkup Kurikulum Pendidikan Agama Kristen," Jurnal Ilmiah Religiosity Entity Humanity (JIREH) 2, no. 1 (2020): 27-38.

${ }^{28}$ Ruth F.Selan, Pedoman Pembinaan Jemaat. 
Aspek yang terakhir dalam menyajikan materi yang akurat memperhatikan sesuai jenjang usia dan kategorial jemaat yang akan dibina. Akan terdapat perbedaan antara materi pembinaan anak-anak dengan remaja, demikian juga dengan usia kategorial lainnya. Dalam rangka menyusun materi pembinaan sesuai usia kategorial dibutuhkan tim kurikulum yang secara akurat mendesain sesuai kategorial usia. Lebih lanjut tim mempertimbangkan struktur materi pembinaan yang berkelanjutan, ada kesinambungan materi pembinaan anak-anak sampai usia lanjut. Jika ini direncanakan dengan baik, akan memberi dampak pada manajemen pelayanan pembinaan yang berkelanjutan dan berkesinambungan.

Point keempat yang mendapat sorotan dalam pembinaan yang akurat ialah metode pelaksanaan. Pembinaan tidak mungkin dipisahkan dari metode yang dilakukan, sebab inilah cara dan strategi menyajikan materi pembinaan dengan akurat. Semua hal yang tekait dalam bagian ini akan dioperasionalkan melalui pelaksanaan pembinaan. Metode pembinaan dapat dilakukan dengan dua cara, yaitu secara langsung, dalam hal ini pendeta sebagai pembina rohani melakukan tatap muka secara langsung dengan jemaat dan memberikan pelajaran rohani. Secara tidak langsung dapat dilakukan melalui buku-buku atau bahan-bahan pelajaran rohani yang dipersiapkan.

Salah satu contoh metode pelaksanaan pembinaan jika lakukan kepada anak-anak dilakukan dengan pola yang tepat, yakni dengan cara memperlakukan mereka sebagai individu yang berharga di mata Tuhan. Karena itu tidak boleh menakut-nakuti mereka dengan ayat-ayat firman yang menyeramkan, harus dengan pendekatan yang cara positif (Wahyu 20:15). Selain itu, menata mereka dalam kelompok bermain yang mudah diatur, dengan berkelompok anak-anak lebih merasa nyaman, karena memang sifat anak-anak cenderung suka bermain.

Dalam hal memberi imbalan kepada anak anak tidak dilarang, hanya perlu memperhatikan pendekatan individual, cara mereka menerima dan merespons hadiah. Pemberian imbalan kepada anak-anak pada dasarnya bukan tidak baik, namun perlu pertimbangan matang kapan dan dimana memberikan hal itu. Setiap respon dari anak-anak hendaknya tidak beri ganjaran berupa "hadiah tertentu" namun lebih kepada tuntunan bagaimana mereka setia dan taat kepada Tuhan.

Dalam konteks mendorong anak-anak meresponi pertobatan, maka cara-cara yang dapat dilakukan oleh pembina atau guru-guru yang mengajar mereka sebagai berikut: (1) Anak dibimbing secara berproses menerima Injil keselamatan, (2) Menuntun anak-anak dengan penuh kasih dalam menerima keselamatan, melalui, pertama, meyakinkan anakanak bahwa Yesus Kristus adalah jalan satu-satunya keselamatan. Kedua, mendorong anakanak mengakui dosa dan meminta ampun kepada Yesus Kristus. Ketiga, menjelaskan upah dosa adalah maut dan mengakibatkan manusia mengalami kematian secara jasmani, rohani dan kematian keal. Keempat, mendorong anak-anak menyadari bahwa dengan percaya akan Kristus, dosa diampuni dan keselamatan menjadi milik mereka.

Memilih metode yang tepat pada dasarnya ada beberapa hal yang perlu diperhatikan, di antaranya waktu pelaksanaan pembinaan. Jika waktu pelaksanaan pembinaan memadai, maka pemilihan metode disesuaikan. Misalnya, waktu pelaksanaan pembinaan 6 bulan dan dilakukan setiap minggu 2 jam pertemuan, pendeta atau gembala yang melaksanakan pembinaan dapat memilih beragam metode misalnya dialog, ceramah dan pembinaan, atau bahkan juga bisa dengan studi kasus. Ketersediaan waktu yang memadai akan memberi peluang bagi pemilihan metode yang bervariasi, tentu hal ini akan berimbas pada kematangan pembinaan yang dilakukan.

Jika waktu yang tersedia bagi pembinaan lebih sedikit, misalnya hanya 2-3 jam, maka bisa diselenggarakan dengan seminar dan pelatihan, namun sifatnya hanya memberikan informasi-informasi yang penting. Selanjutnya jemaat dapat didorong belajar secara mandiri. 
Jumlah waktu pembinaan ekivalen dengan metode, maka pada prinsipnya pemilihan cara penyajian pembinaan sangat tergantung pada waktu pelaksanaan pembinaan rohani.

Selain waktu hal yang penting mendapat perhatian dalam metode pembinaan ialah kemampuan atau keterampilan pendeta atau gembala yang melaksanakan pembinaan tersebut. Ukuran keterampilan dan kemampuan memang tidak bisa dilakukan secara akurat, namun berdasarkan pengalaman dan juga rekam jejak pendeta, sedikit banyak dapat diprediksi tentang kemampuan tersebut. Salah satu hal yang mudah untuk mengetahui keterampilan dan kemampuan pendeta yakni dengan melihat pelayanan dan tugas penggembalaan sehari-hari. Misalnya dalam hal menyampaikan firman Tuhan (khotbah), pendeta atau gembala jemaat yang terampil sudah pasti mempersiapkan bahan khotbah dengan akurat dan juga memenuhi kerangka yang tepat.

Peningkatan atau mengupgrade ketrampilan pendeta dalam melakukan pembinaan rohani, dapat dilakukan dengan mengikuti pelatihan dan seminar. Upgrading tentu sudah menjadi kebutuhan pendeta dan gembala di masa kini. Hal ini dipengaruhi jemaat-jemaat yang semakin kritis, jemaat-jemaat yang juga mulai terbuka dan terdorong untuk belajar secara terbuka. Jemaat pada umumnya dengan mudah membandingkan isi dan kualitas pembinaan, dengan gereja-gereja lain, sebab itu pendeta yang tidak mau meng-upgrade diri akan mengalami kesulitan. Salah satu cara untuk meng-upgrade keterampilan dan kemampuan pendeta dalam melakukan pembinaan rohani, dapat ditempuh dengan training-training yang disediakan oleh lembaga-lembaga tertentu atau juga oleh sinode dimana pendeta yang bersangkutan bernaung. Selain itu dapat juga ditempuh dengan pendidikan akademik yang diselenggarkan oleh institusi pendidikan. Intinya ialah bahwa pendeta atau gembala wajib meningkatkan kemampuan dan ketrampilan dalam membina jemaat-jemaat.

Hal yang kelima dalam bagian ini yakni sistem evaluasi seluruh pelaksanaan pembinaan rohani. Pembinaan warga gereja selalu diawali dengan perencanaan dilanjutkan dengan pelaksanaan kemudian diakhiri dengan evaluasi. Bagian akhir ini sering dilupakan pada hal ini akan memberikan gambaran seberapa efektif atau seberapa efisien pembinaan yang dilakukan. Tujuan evaluasi pembinaan rohani akan mengukur capaian atau indikator keberhasilan program pembinaan.

Salah satu cara mengevaluasi program yang telah dilakukan yakni dengan memperhatikan perencanaan yang ada, jika semua atau mayoritas perencanaan telah dilaksanakan, maka secara progresif kegiatan dapat disebutkan berhasil. Akan tetapi untuk mengukur efektivitasnya harus memperhatikan pencapaian tujuan. Tujuan dalam hal ini bisa dalam kategori kuantitas dan juga kualitas. Jika tujuan yang dicapai berdasarkan kuantitas maka patokan dasar yang dipakai lebih kepada frekuensi program pembinaan dan jumlah jemaat yang mengikuti kegiatan, sedangkan jika kualitas yang menjadi indikator yang harus dilakukan ialah gereja dalam hal ini pendeta harus mampu mengukur pertumbuhan kerohanian jemaat.

Mengetahui apakah program pembinaan memiliki pengaruh yang signifikan bagi jemaat, gereja dapat membuat kuestioner yang diisi oleh peserta pembinaan. Dengan metode ini ada banyak keuntungan yang didapatkan antara lain, gereja dapat mengukur pencapaian tujuan, mengukur efektivitas program, bahkan juga kemanfaatan pembinaan. Selain itu lembar angket yang diberikan pun akan memberikan deskripsi tentang hal-hal yang perlu mendapat perhatian untuk diperbaiki. Keseimbangan antara pencapaian tujuan dengan hal-hal yang masih diperbaiki, tentu hal ini jika direspons secara positif akan memberi dampak baik bagi pembinaan selanjutnya. 
Implementasi program yang kreatif

Program yang kreatif merupakan faktor penting diperhatikan dalam strategi implementasi pembinaan yang efektif. Program-program yang kreatif akan mendorong minat dan motovasi jemaat dalam mengikuri pembinaan rohani. Kecenderungan program jika dilakukan secara monoton dan biasa-biasa saja, maka tidak menimbulkan animo yang besar dari anggota jemaat. Beberapa indikator program yang kreatif diantaranya kegiatan yang dilakukan menarik perhatian jemaat-jemaat, juga kegiatan yang dilakukan bersinggungan dengan kebutuhan kerohanian jemaat.

Dalam merealisasikan program yang kreatif dapat dilihat dari berbagai hal, pertama, jenis dan macam program yang dilaksanakan bervariasi. Gereja dalam hal ini pendeta atau gembala jemaat harus menghindari program yang konvensional, dan tidak berubah dari tahun ke tahun. Gereja harus secara proaktif menemukan bentuk-bentuk program yang memberi kontribusi positif bagi jemaat-jemaat, minimal hal ini mensuplai kebutuhan antar golongan, kategorial usia di gereja lokal. Selain itu program juga tidak monoton hanya di gereja, melainkan di luar gereja juga dikemas sesuai dengan perencanaan yang akurat.

Beberapa pilihan program pembinaan yang bisa dilakukan dalam gereja lokal, antara lain; pertama, pemuridan. Sesuai dengan amanat Matius 28:19-20, salah satu tugas gereja adalah memuridkan. Subekti menjelaskan dalam perjanjian baru konsep pemuridan itu terdiri dari tiga layer yakni tiga murid, dua belas murid, dan tujuh puluh murid, tentu bagian ini hendak menjelaskan klasifikasi pemuridan dan urgensi pemuridan. Dalam hal ini tugas yang paling pokok dalam pemuridan ialah menanamkan gaya hidup dan nilai-nilai kerajaan Allah. ${ }^{29}$ Dalam konteks realisasi pemuridan dalam masa kini, hal yang perlu dilakukan pendeta kepada jemaat yakni membina mereka melalui kelas pemuridan yang mengajarkan tentang tugas dan tanggung jawab murid.

Lebih lanjut pemuridan dalam gereja lokal dapat didesain semi klasikal. Misalnya ada bagian-bagian yang dilakukan secara pengajaran klasikal kepada jemaat-jemaat, namun juga yang secara personal pendeta membangun hubungan dengan mereka. Memadukan kedua hal ini sangatlah penting sebab pada prinsipnya hal-hal yang informal jauh lebih mampu mempengaruhi jemaat ketimbang hanya kelas pengajaran. Untuk ini pendeta harus membangun komunikasi yang intens dan perlu mendapat feedback tentang agenda-agenda pemuridan dan kelanjutannya.

Pemuridan pada dasarnya menghasilkan murid yang dewasa, ukuran kedewasaan itu jika murid menghasilkan murid. Putu Darmawan menjelaskan bahwa esensi pokok pemuridan dalam Matius 28:19-20, ialah memuridkan bangsa-bangsa yang dimulai dari langkah yang sederhana memuridkan satu orang dan kemudian bermultiplikasi secara intens, ${ }^{30}$ dalam gambaran multiplikasi dapat dicontohkan seperti Paulus memuridkan Timotius, lalu Timotius memuridkan orang-orang percaya lainnya. Pola ini jika dikembangkan secara sistematis, maka akan membawa pertambahan jumlah orang-orang percaya. Selain itu, Hutagalung menjelaskan bahwa pemuridan memiliki nilai misi, yang mendorong jemaat-jemaat memenangkan jiwa-jiwa. ${ }^{31}$

Pemuridan dapat direncanakan dalam gereja sesuai dengan kebutuhan di lapangan. Dalam hal waktu yang dibutuhkan, materi atau isi pemuridan, dan juga narasumber dalam pemuridan, maka semua dilaksanakan sesuai kondisi setempat. Pendeta atau gembala

29 Tri Subekti, "Pemuridan Misioner Dalam Menyiapkan Perluasan Gereja Lokal,"

EPIGRAPHE: Jurnal Teologi dan Pelayanan Kristiani 3, no. 2 (2019): 157.

${ }^{30}$ I Putu Ayub Darmawan, "JADIKANLAH MURID: TUGAS PEMURIDAN GEREJA

MENURUT MATIUS 28:18-20," Evangelikal: Jurnal Teologi Injili dan Pembinaan Warga Jemaat (2019).:149

31 Patrecia Hutagalung, "Pemuridan Sebagai Mandat Misi Menurut Matius 28:18-20,"

Pengarah: Jurnal Teologi Kristen 2, no. 1 (2020): 64-76. 
jemaat adalah pribadi yang paling bertanggung jawab dan sangat memahami tentang halhal ini.

Kedua, komsel (komunitas sel). Komsel adalah wadah kelompok kecil yang berfungsi menggembalakan jemaat-jemaat dan bisa juga dipakai sebagai pemuridan. ${ }^{32}$ Komsel yang sering disebut dengan kelompok kecil adalah komunitas yang terdiri dari tidak lebih dari 12 orang yang secara bersama-sama berkumpul dan belajar bersama tentang firman Tuhan. Ini merupkan salah satu cara yang efektif dalam membina rohani jemaat. Komsel pada prinsipnya bukan sekedar kegiatan persekutuan rutin, melainkan kegiatan mingguan yang diselenggarakan untuk pengajaran yang sistematis. Dalam hal ini materi-materi komsel bisa didapatkan dari materi khotbah mingguan, atau bisa juga didesain dalam bentuk buku tertentu. Keuntungan materi komsel dengan pola ini akan mudah digunakan dan juga mudah dievaluasi. Selain hal itu pembuatan materi komsel jika dilakukan secara tertulis akan memudahkan mendesain kelanjutan setiap tahunnya. Pelaksanaan komsel dapat memberi pengaruh yang positif bagi pertumbuhan kerohanian, komsel pada dasarnya bukan hanya agenda persekutuan rutin melainkan wadah pengembangan kemampuan dan juga karunia-karunia jemaat-jemaat. Dengan komsel jemaat-jemaat dapat diberdayakan untuk tugas-tugas pelayanan, dan dengan terlibat dalam pelayanan maka peluang yang besar jemaat mengalami pertumbuhan semakin terbuka.

Ketiga, sekolah orientasi melayani (SOM). Bentuk yang ketiga ini lebih formal karena muatannya kurikulum pengajaran teologia yang secara praktis. Dalam gereja lokal ini bisa dilakukan secara informal, misalnya dengan memberi kelas pengajaran 2 jam setiap minggu. Kelas ini diempuh 6 bulan atau 12 bulan, sesuai dengan keperluan di jemaat lokal. Oleh karena SOM lebih banyak mempelajari Alkitab secara advance, maka jemaat-jemaat yang mengikuti program ini diharapkan memenuhi prasayarat, seperti telah bertobat, terlibat dalam pelayanan, memiliki kerinduan dalam tugas-tugas pelayanan, dan lain-lain.

Keempat, konseling pribadi. Konseling pribadi dapat juga menjadi sarana pembinaan rohani terkait dengan hal-hal atau masalah yang dialami. Konseling sebagai pembinaan rohani pada prinsipnya dengan cara dialog atau komunikasi menyelesaikan masalah yang dihadapi, secara simultan juga pengajaran dan pembinaan rohani dilakukan. Kecenderungan pelaksanaan konseling pribadi memang lebih banyak diarahkan menyelesaikan pergumulan dan masalah. Namun dengan cara dialog antara konseli dengan konselor, umumnya pengajaran disampaikan, pembinaan dilakukan. Pendeta yang memanfaatkan konseling sebagai pembinaan harus dengan detail dan secara seksama melakukannya berdasarkan firman Tuhan.

Bentuk-bentuk pembinaan yang kreatif masih banyak lagi, tidak semua dijelaskan dalam bagian ini, misalnya, melakukan program SPK (Saya Pengikut Kristus), SPY (Saya Pengikut Yesus), BSK (Bapa Sepanjang Kehidupan), Kelompok Tumbuh Bersama, Retreat, Doulos Camp, dan lain-lain. Semua bentuk program kreatif ini dapat dilakukan secara bergantian, sesuai dengan kesiapan gereja yang bersangkutan. Dengan melakukan programprogram ini diharapkan jemaat tidak terjebak dalam agenda yang monoton dan konsvensional.

Implementasi program kreatif, pada dasarnya menolong pendeta atau gembala jemaat merancangkan dan menetapkan langka-langkah strategis serta mampu membentuk model pembinaan yang efektif dalam mendewasakan jemaat-jemaat. Pembinaan akan menjadi spesifik, dan tidak dilakukan hanya untuk membuat daftar program gereja, melainkan berupaya mencapai sasaran pendewasaan warga jemaat yang ditandai dengan perubahan karakter, kedewasaan iman melalui kemampuan memahami firman Tuhan dan terlibat dalam pelayanan.

32 Yoseph P. Bising, “Apakah Kelompok Sel Itu?,” Jurnal Kurios Vol 1(1), 2018:35. 


\section{Kehidupan dan Karakter Pemimpin Rohani}

Hal yang tidak kalah penting dalam konteks mengerjakan pembinaan rohani yang efektif ialah menyangkut karakter dan kehidupan pemimpin rohani (pendeta atau gembala jemaat. Mengapa hal ini penting? Hal yang menjadi perhatian yakni jemaat membutuhkan figur dan teladan seorang pelayan Tuhan. Dalam membina kerohanian jemaat, maka bukan hanya skill dan keterampilan yang menjadi fokus utama, juga bukan soal karunia dalam pelayanan yang menjadi tolok ukur melainkan kehidupan dan karakter.

Kriteria dan prasyarat pendeta atau pemimpin rohani di jemaat lokal harus menjadi perhatian serius dalam melaksanakan pembinaan rohani, tentu hal ini sudah menjadi hak yang umum, pelayanan yang dilakukan bukan soal hal-hal manusiawi melainkan spiritual. Itulah sebabnya penting karakter, keteladanan dan kerohanian para pemimpin rohani. Secara prinsip beberapa hal menyangkut kehidupan dan karakter pendeta dalam melakukan pembinaan rohani, yakni:

Pertama, memiliki hati yang baru. Pendeta atau gembala jemaat haruslah sudah bertobat dan lahir baru. Dalam tugas pembinaan ia memberi teladan pertobatan kepada jemaat-jemaat, ia pun dipakai oleh Tuhan memperkenalkan Kristus kepada jemaat-jemaat (Yoh 3:3; 1 Kor 2:14; 2 Kor 5:17). Kedua, memiliki hati yang lapar firman Tuhan. Pendeta dan gembala jemaat adalah pribadi yang harus memiliki kerinduan akan Firman Tuhan. Salah satu hal yang dapat dilakukan untuk hal ini ialah mereka haruslah menjadi pelaku Firman Tuhan dan bersekutu dengan firman itu (1 Pet. 2:2; Yoh. 6:35). Ketiga, hati yang disiplin. Pendeta dan gembala jemaat harus mempunyai hati yang disiplin dan tidak mudah putusasa dalam melaksanakan pembinaan rohani. Hati yang disiplin menolong pemimpin rohani melayani secara konsisten, berapi-api dan tanpa pamrih (Rom. 12:11; 2 Kor. 4:8). Keempat, hati yang mengasihi. Dalam mengerjakan tugas pembinaan, pendeta atau gembala jemaat harus mempraktikkan kasih kepada jemaat-jemaat. Jemaat tidak boleh dibedabedakan, bahkan tidak boleh juga melakukan tebang pilih dalam melayani jemaat-jemaat. Bagaimanapun model jemaat yang dilayani harus dilakukan dengan kasih (Yoh. 3:16; Ef. 4:12).

Kelima, hati yang beriman. Pemimpin rohani haruslah senantiasa bersandar pada Tuhan dan bukan kepada kekuatan sendiri, karena Dialah yang memimpin dan menolong kita (Ams. 3:5; 2 Tim. 1:12). Dalam melakukan tugas pembinaan rohani, harus mengandalkan Roh Kudus, tidak boleh mengandalkan kekuatan dan kemampuan sendiri. Keenam, hati rela diajar. Ini adalah kunci bagi pemimpin rohani dalam menjalankan tugas pembinaan rohani, belajar dan mengajar dalam konteks pembinaan iman tidak mungkin dipisahkan dari mereka (Yes. 50:4, 1 Tim. 4:6). Ketujuh, hidup kudus. Kekudusan menjadi hal yang prinsip bagi pemimpin rohani dalam menjalankan tugas pelayanan, secara khusus pembinaan rohani. Hidup suci adalah modal utama bagi pendeta dan gembala sehingga mereka berkenan kepada Tuhan (1 Pet. 1:15).33

Dengan memiliki karakter yang baik sesuai firman Tuhan, maka pelayanan pembinaan rohani yang dilakukan oleh pendeta dan gembala jemaat, memiliki peluang untuk membawa jemaat bertumbuh dengan dewasa dalam iman. Selain masalah karakter hal yang penting diperhatikan dalam hal ini adalah karunia yang dimiliki pendeta. DeVris menjelaskan bahwa karunia rohani akan memberi pengaruh yang besar bagi keberhasilan dan pelayanan hamba Tuhan. ${ }^{34}$ Oleh karena pekerjaan dan pelayanan pendeta dan gembala 2006), 25 .

${ }_{33}$ Paulus Kristianto, Prinsip Dan Praktik Pendidikan Agama Kristen, (Jogjakarta: Andi Offset,

${ }^{34}$ Brian A. DeVries, "Spiritual Gifts for Biblical Church Growth," In die Skriflig/In Luce Verbi (2016). 
jemaat bukan hal-hal yang jasmaniah maka sangat diharapkan dalam melaksanakan tugas tersebut, memelihara persekutuan dengan Tuhan adalah hal yang utama dan tidak bisa tergantikan.

\section{Implikasi}

Penelitian dengan strategi gereja membina rohani secara efektif memberikan solusi bagi pendeta atau gembala jemaat dalam merancangkan bentuk-bentuk pembinaan yang spesifik. Pembinaan tidak dilakukan hanya untuk memperbanyak program gereja melainkan berupaya mencapai sasaran yang terencana, terukur, dan berdampak bagi pendewasaan rohani jemaat. Pendeta atau bidang pembinaan jemaat akan mampu secara akurat mendisain pola-pola pembinaan yang efektif dan berpengaruh pada peningkatan partisipasi jemaat dalam pelayanan gereja sebagai wujud kedewasaan rohani.

\section{Rekomendasi Penelitian Lebih Lanjut}

Strategi pembinaan rohani jemaat pada dasarnya memiliki banyak aspek yang perlu diperhatikan. Untuk penelitian lebih lanjut disarankan menghubungkan pembinaaan warga gereja dengan penyiapan kurikulum pembinaan berbasis visi jemaat lokal. Hal ini menjadi penting sebab untuk mencapai efektivitas pembinaan salah satu ukurannya ialah dengan menemukan apakah visi jemaat lokal tercapai atau tidak.

\section{Kesimpulan}

Program pembinaan warga gereja merupakan tanggung jawab pemimpin rohani atau pendeta jemaat. Hal ini merupakan tugas dan tanggung jawab dalam rangka menjalankan amanat agung. Untuk dapat melaksanakan pembinaan warga gereja secara efektif pendeta harus melakukan analis yang akurat sehingga mampu menetapkan langkah strategis pelayanan yang dilakukan dengan mengetahui kebutuhan rohani jemaat, merancangkan program yang sesuai dengan tingkat dan kedewasaan rohani jemaat, serta juga memperhatikan keragaman anggota jemaat.

Dalam rangka menentukan agar program pembinaan rohani berjalan dengan baik yang harus dilakukan pendeta atau gembala jemaat yakni memilih program yang tepat, akurat dan kreatif. Ketepatan program pembinaan warga jemaat karena berbasis analisa kebutuhan dan keadaan rohani jemaat, keakuratan diukur dengan kesesuaian dengan visi dan misi gereja, dan dimplementasikan dalam kegiatan mingguan, bulanan, serta tahunan. Sedangkan unsur kreatif program diterapkan melalui variasi program pembinaan (pemuridan, doulos camp, BSK, SPY, SPK, dan lain-lain) dan ini dapat dijadikan menjadi model pembinaan yang efektif mendewasakan kerohanian jemaat. Jadi model pembinaan yang mampu mendewasakan jemaat yakni direncanakan berdasarkan analisa kerohanian jemaat, setelah itu membuat program-program yang konkrit dan melibatkan jemaat melalui berbagai kegiatan yang variatif, baik di gereja maupun di rumah jemaat-jemaat, juga dapat dilakukan secara kelompok atau individu.

\section{Rujukan}

Berhitu, Reinhard Jeffray. "Peran Gembala Jemaat Terhadap Pengembangan Pelayanan Holistik Di Gereja Kemah Injil Indonesia Jemaat Yegar Sahaduta Jayapura." Jurnal Jaffray 12, no. 2 (2014): 273.

Bising, Yoseph P. “Apakah Kelompok Sel Itu?” Kurios (2018).

Borrong, Robert P. Melayanui Makin Sungguh $\square$ : Signifikansi Kode Etik Pendeta Bagi Pelayanan Gereja-Gereja Di Indonesia. Jakarta: BPK Gunung Mulia, 2016.

Camerling, Yosua, and Hengki Wijaya. “Misi Dan Kebangkitan Rohani: Implikasi Misi Allah 
Bagi Gereja." Jurnal Ilmiah Religiosity Entity Humanity (JIREH) 1, no. 1 (2019): 57-71.

DeVries, Brian A. "Spiritual Gifts for Biblical Church Growth." In die Skriflig/In Luce Verbi (2016).

Diana, Ruat. "Permasalahan Pembinaan Warga Gereja Di Kewari." Evangelikal: Jurnal Teologi Injili dan Pembinaan Warga Jemaat (2018).

Francis O. Ayres. Pembinaan Warga Gereja Pelayanan Kaum Awam. Edited by Putri Kapandeyan. Pertama. Malang: Gandum Mas, 2016.

Gidion, Gidion. "PROFESIONALITAS LAYANAN GEREJA." Shift Key $\square$ : Jurnal Teologi dan Pelayanan (2017).

Hutagalung, Patrecia. "Pemuridan Sebagai Mandat Misi Menurut Matius 28:18-20." Pengarah: Jurnal Teologi Kristen 2, no. 1 (2020): 64-76.

I Putu Ayub Darmawan. "JADIKANLAH MURID: TUGAS PEMURIDAN GEREJA MENURUT MATIUS 28:18-20." Evangelikal: Jurnal Teologi Injili dan Pembinaan Warga Jemaat (2019).

Mika, Mika, and Petronella Tuhumury. "Implementasi Strategi Pembinaan Menuju Pertumbuhan Rohani Pemuda Gkii Jemaat Sidu'ung Muara Berau." Jurnal Jaffray (2013).

Moleong, Lexy L. Metode Penelitian Kualitatif. Bandung, 2004.

Nuhamara, Daniel. "Pengutamaan Dimensi Karakter Dalam Pendidikan Agama Kristen." Jurnal Jaffray 16, no. 1 (2018): 93.

Pasaribu, Andar Gunawan, and Rida Gultom. Pembinaan Warga Gereja. Edited by Dane Taruli Simamora. Pertama. Medan: Penerbit MITRA, 2015.

R.M. Drie S. Brotosudarmo. "Pembinaan Warga Gereja Selaran Dengan Tantangan Zaman." 197. 2nd ed. Jogjakarta: Andi OffSet, 2017.

Selan, Ruth F. Pedoman Pembinaan Jemaat. Bandung: Kalam Hiduo, 2006.

Sembiring, Ngendam. "Mengatasi Degradasi Moral Melalui Pembinaan Warga Gereja." ILLUMINATE: Jurnal Teologi dan Pendidikan Kristiani 1, no. 1 (2018): 22-42.

Subekti, Tri. "Pemuridan Misioner Dalam Menyiapkan Perluasan Gereja Lokal." EPIGRAPHE: Jurnal Teologi dan Pelayanan Kristiani 3, no. 2 (2019): 157.

Sugiyono. Metode Penelitian Kualitatif. Bandung: Alfabeta, 2009.

Sumarto, Yonathan, and Peter Anggu. "Pembinaan Kerohanian Gereja Bethel Tabernakel Dalam Konteks Kebudayaan Toraja." Jurnal Jaffray 8, no. 1 (2010): 24-34. https://ojs.sttjaffray.ac.id/JJV71/article/view/39.

Supartini, Tri. "Implementasi Teologia Anak Untuk Mewujudkan Gereja Ramah Anak." Integritas: Jurnal Teologi 1, no. 1 (2019): 1-14.

Tafonao, Talizaro. "Peran Gembala Sidang Dalam Mengajar Dan Memotivasi Untuk Melayani Tehadap Pertumbuhan Rohani Pemuda." Evangelikal: Jurnal Teologi Injili dan Pembinaan Warga Jemaat 2, no. 1 (2018): 85-92.

Tubulau, Imanuel P. "Kajian Teoritis Tentang Konsep Ruang Lingkup Kurikulum Pendidikan Agama Kristen." Jurnal Ilmiah Religiosity Entity Humanity (JIREH) 2, no. 1 (2020): 27-38.

Yachina, Nadezhda. "The Problem of Spiritual and Moral Formation of Personality." Procedia - Social and Behavioral Sciences 197, no. February (2015): 1575-1579. 